\title{
CENTRAL ASIAN GEODYNAMIC REGIMES WEST AND EAST 102-104 GEODIVIDER
}

\author{
Yu.G. Gatinsky ${ }^{1}$, T.V. Prokhorova ${ }^{1}$, D.V. Rundquist ${ }^{2}$
}

${ }^{1}$ Institute of Earthquake Prediction Theory and Mathematical Geophysics of RAS, Moscow, Russia

${ }^{2}$ V.I. Vernadsky State Geological Museum of RAS, Moscow, Russia

ABSTRACT. Ample geologic and geophysical data provide the basis for distinguishing the $102-104^{\circ}$ E geodivider in the North, Central and South Asia. The geodivider's central part is confirmed by the data on seismicity, seismically active faults and the modern crust block structure. These data and historical and instrumentally identified earthquake epicenters were used for a more correct definition of the block boundaries and interblock zones in the central part of the geodivider and in its wings. Seismic energy is considerably increased (to $10^{11}-10^{16} \mathrm{~J}$ ) in the eastern part of the geodivider's western wing, and rarely increased directly in the geodivider itself. Near the geodivider, a seismic energy increase is detected east of it only at the western border of the South-Eastern China Block. The authors analyzed deep seismic sections and constructed energy dissipation graphs along transects crossing the geodivider and its western wing. The analysis and the graphs show the predomination of left-lateral NW-striking slips in the north, thrusts to the east and southeast in the center, and right-lateral NE-striking slips in the south. The total seismic energy increases constantly to the west. In the central and northern segments of the geodivider's central part and west of it, horizontal blocks displacements cause a direct influence on seismicity level increasing and changes in geodynamic regimes within the investigated territory of Central Asia. Changes in the horizontal displacement vector are accompanied by the change of tectonic strain regimes. Increased heat flow values to the east from the geodivider within the East Asian transit zone are probably related to the change of the geodynamic regimes in the same direction under the influence of the submerged Pacific slab. The data obtained by the Chinese and Russian researchers confirm delamination (stratification) processes in the Southeast Tibet crust during its interaction with the colder and thicker lithosphere of Southeast China, and displacement of its upper layers to the southeast and south, as we supposed in our earlier publications.

KEYWORDS: geodynamic regime; geodivider; transitional zone; block; interblock zone; seismicity; seismic energy; heat flow; geophysical field; lithosphere tomography

FUNDING: The study was carried out under the state assignment AAAA-A19-119011490127-6 and supported by RFBR (Project 18-05-00160). 


\title{
ГЕОДИНАМИЧЕСКИЕ РЕЖИМЫ ЦЕНТРАЛЬНОЙ АЗИИ ЗАПАДНЕЕ И ВОСТОЧНЕЕ ГЕОРАЗДЕЛА 102-104
}

\author{
Ю.Г. Гатинский ${ }^{1}$, Т.В. Прохорова ${ }^{1}$, Д.В. Рундквист ${ }^{2}$
}

\author{
${ }^{1}$ Институт теории прогноза землетрясений и математической геофизики РАН, Москва, Россия \\ ${ }^{2}$ Государственный геологический музей им. В.И. Вернадского РАН, Москва, Россия
}

\begin{abstract}
АНнотАция. Геораздел 102-104 в.д. выделяется по многочисленным геологическим и геофизическим признакам в Северной, Центральной и Южной Азии, подтверждаемым в его центральной части данными по сейсмичности, сейсмоактивным разломам и современному блоковому строению земной коры. На основании этих данных и по распространению эпицентров инструментально зафиксированных и исторических землетрясений откорректированы границы блоков и межблоковых зон в центральной части геораздела и на его крыльях. Значительное возрастание объемов высвобождающейся сейсмической энергии до $10^{11}-10^{16}$ Дж происходит в восточной части западного крыла геораздела, реже - непосредственно в нем, а к востоку от него - только на западной границе блока Юго-Восточного Китая вблизи геораздела. Проведенный авторами анализ глубинных сейсмических разрезов и графиков диссипации энергии вдоль трансектов, пересекающих геораздел и его западное крыло, показывает преобладание левосторонних сдвигов с северо-западным простиранием на севере, надвигов к востоку и юго-востоку в центре и правосторонних сдвигов с северо-восточным простиранием на юге. Общий уровень объема энергии постоянно возрастает к западу. Перемещения по горизонтали блоков в центральном и северном сегментах центральной части геораздела $102-104^{\circ}$ в.д. и к западу от него по данным GPS оказывают непосредственное влияние на увеличение уровня сейсмичности и изменение геодинамических режимов в пределах изучаемых районов Центральной Азии. Смена направления векторов горизонтального перемещения сопровождается изменением режима тектонических напряжений. Установлено возрастание значений теплового потока к востоку от геораздела в Восточно-Азиатской транзитной зоне, предположительно связанное со сменой геодинамического режима в том же направлении под влиянием погруженного тихоокеанского слэба. Данные по сейсмической анизотропии и томографии литосферы, полученные китайскими и российскими исследователями, подтверждают процессы деламинации коры Юго-Восточного Тибета при ее взаимодействии с более холодной и мощной литосферой Юго-Восточного Китая и перемещение ее верхних слоев к юго-востоку и к югу, предполагавшееся в более ранних работах авторов.
\end{abstract}

КЛЮЧЕВЫЕ СЛОВА: геодинамический режим; геораздел; транзитная зона; блок; межблоковая зона; сейсмичность; сейсмическая энергия; тепловой поток; геофизическое поле; томография литосферы

ФИНАНСИРОВАНИЕ: Проведенное исследование выполнено в рамках темы государственного задания АААА-А19-119011490127-6 и при поддержке РФФИ (проект № 18-05-00160).

\section{1. ВВЕДЕНИЕ}

Квазилинейная зона заметных геологических и геодинамических изменений отчетливо устанавливается на территории Центральной Азии при анализе Электронного геодинамического глобуса (http://ears.jscc.ru) и других геологических материалов. Она приблизительно совпадает с меридианами 102-104 в.д., характеризуется в своей центральной части преимущественно сильной и значительной сейсмичностью и развитием сейсмоактивных разломов различного простирания, в том числе совпадающих с простиранием зоны. Авторы совместно с С.В. Черкасовым назвали ее в докладе на МГК 2004 «Георазделом 102-103 в.д.» [Rundquist et al., 2004; Gatinsky et al., 2005]. Однако на современном этапе при более детальном изучении сейсмичности и других геофизических характеристик этой зоны мы пришли к выводу о ее более широком распространении от 102 до 104, хотя нельзя исключить, что при дальнейшем изучении ее восточная граница может отодвинуться еще далее к востоку.
Часть этой структуры, разделяющей в тектоническом отношении Центральную и Восточную Азию, в 70-х годах XX века относилась к «Зоне ВЕБИРС» [Komarov et al., 1978]. Позднее более отчетливо различие геодинамики к западу и к востоку от нее было показано в работах [Grachev et al.,1993; Kuchai, Kozina, 2010]. В последнее время эта зона называлась также «North-South Seismic Belt - NSSB» [Wang X. et al., 2015], «North-South Tectonic Belt - NSTB» [Chang et al., 2015], «Глобальной меридиональной пограничной структурой» [Sherman, 2016]. Центральная часть геораздела совпадает на глубине с крупными градиентами мощности коры и всей литосферы, гравитационной ступенью, изменением скоростей $S$-волн в верхней мантии и с развитием низкоскоростных зон в верхней и средней коре. Она, в первом приближении, разделяет две основные транзитные зоны Центральной и Восточной Азии (рис. 1). На западе это Центрально-Азиатская зона между Северо-Евразийской и Индийской литосферными плитами с развитием режима транспрессии с надвигами и сдвигами 


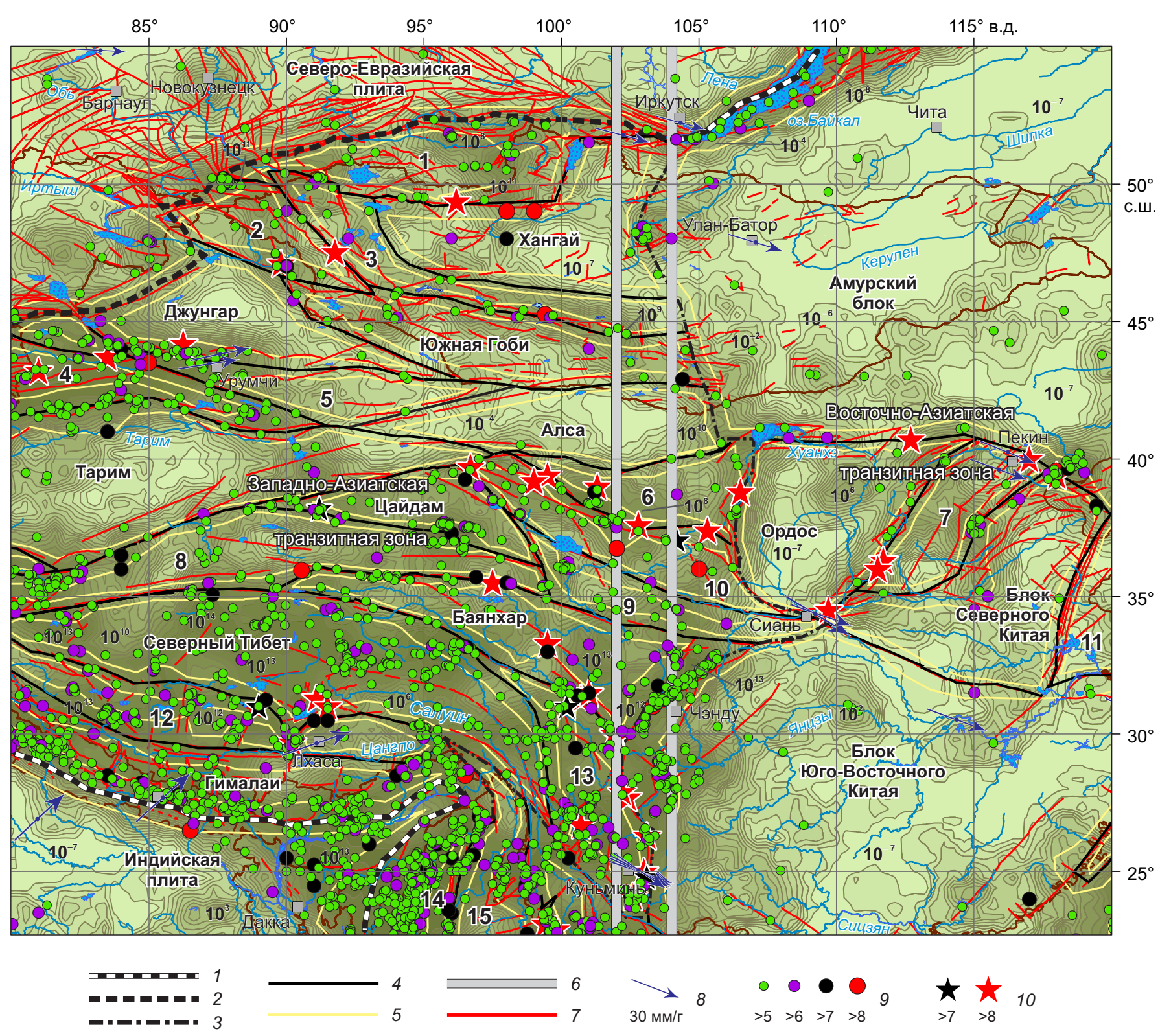

Рис. 1. Геораздел $102-104^{\circ}$ в.д. в блоковой структуре Центральной и Восточной Азии.

1-6 границы: 1 - литосферных плит, 2 - предполагаемые границы плит, 3 - транзитных зон, 4 - блоков, 5 - межблоковых зон, 6 - геораздела; 7 - активные разломы [Trifonov et al., 2002; Gatinsky et al., 2011; Sherman, 2012, 2015]; 8 - экспериментальные ITRF векторы горизонтальных перемещений плит и блоков (http://itrf.ign.fr /ITRF_solutions/2014/); 9 - эпицентры инструментально замеренных землетрясений по данным NEIC2018; 10 - эпицентры исторических землетрясений с VIII до XIX века [Xu, Deng, 1996]. Зелено-оливковая заливка соответствует объемам сейсмической энергии по расчетам авторов статьи: каждое увеличение интенсивности окраски отвечает возрастанию энергии на 10 Дж. На схеме подписаны отдельные значения энергии в джоулях.

Цифрами обозначены блоки: 1 - Саяны, 2 - Алтай, 3 - Юго-Западной Монголии, 4 - Тянь-Шань, 5 - Бей-Шань, 6 - Джартай, 7 - Тайханг-Шань, 8 - Восточный Кунлунь, 9 - Западный Цинлин, 10 - Цилян, 11 - Японско-Корейский, 12 - Южный Тибет, 13 - Кам Диан, 14 - Западно-Бирманский, 15 - Шан. Схема составлена авторами статьи.

Fig. 1. The $102-104^{\circ}$ E geodivider in the block structure of Central and East Asia.

The scheme is consolidated by the authors of this article. 1-6 - boundaries of: 1 - lithosphere plates, 2 - supposed boundaries of plates, 3 - transitional zones, 4 - blocks, 5 - interblock zones, 6 - geodivider; 7 - active faults (after [Trifonov et al., 2002; Gatinsky et al., 2011; Sherman, 2012, 2015]); 8 - computer-simulated ITRF vectors of horizontal displacement of plates and blocks (http:// itrf.ign.fr/ITRF_solutions/2014/); 9 - epicenters of instrument measured earthquakes (NEIC 2018 data); 10 - epicenters of historical earthquakes (from the 8th to 19th centuries [Xu, Deng, 1996]). The intensity of olive-green colour corresponds to seismic energy amounts estimated by the authors of this article, and each deeper colour reflects a seismic energy increase by $10 \mathrm{~J}$ (against the previous one). Energy amounts shown in the scheme are given in joules.

Numbered blocks: 1 - Sayan, 2 - Altai, 3 - SW Mongolia, 4 - Tien-Shan, 5 - Bei-Shan, 6 - Jartai, 7 - Taihang-Shan, 8 - East Kunlun, 9 West Qinlin, 10 - Qilian, 11 - Japanese-Korean, 12 - South Tibet, 13 - Kam Dian, 14 - West Burmese, 15 - Shan. 
со сжатием. В этой зоне отмечалось преобладание большинства эпицентров сильных землетрясений к западу от геораздела [Gatinsky, Rundquist, 2004; Sherman et al., 2015]. В последней работе границы центральной части геораздела в его южном сегменте совпадают с принятыми авторами в настоящей статье, но на севере проведены несколько иначе с отклонением геораздела на восток, к западной границе блока Ордос.

К востоку от геораздела расположена ВосточноАзиатская транзитная зона между Северо-Евразийской, Австралийской и Тихоокеанской плитами, характеризующаяся преобладанием режима транстенсии с образованием сдвигов и структур растяжения [Gatinsky et al., 2011, 2017a].

Детальное изучение геораздела и разделенных им частей транзитных зон позволяет с новых позиций интерпретировать современную геодинамику Центральной Азии, соотношение ее поверхностных структур и их кинематики с геофизическими полями и глубинными аномалиями в коре и верхней мантии и установить главные причины различия тектонических режимов на западе и востоке этого региона. В настоящей работе рассматривается геодинамика наиболее четко выраженной центральной части геораздела и расположенных к западу и востоку от нее Центрально-Азиатской и Восточно-Азиатской транзитных зон, ее соотношение с поверхностными и глубинными структурами и различными геофизическими полями.

\section{2. МЕТОДЫ ИССЛЕДОВАНИЯ}

При изучении современной геодинамики транзитных зон Центральной Азии и разделяющего их геораздела $102-104^{\circ}$ в.д. авторами были задействованы следующие геолого-геофизические методы:

- уточнение границ блоков, межблоковых зон изучаемого региона и геораздела по данным Электронного геодинамического глобуса (http://ears.jscc.ru), материалов дистанционного зондирования (космоснимки) и анализа сейсмоактивных разломов [Xu, Deng, 1996; Trifonov et al., 2002; Seminskii, 2008; Sherman, 2012; Wang X. et al., 2015; Wang Ch. et al., 2015];

- анализ пространственно-временного распределения эпицентров землетрясений в пределах геораздела и внутри смежных транзитных зон и тензоров сейсмического момента по данным электронных каталогов NEIC 2018 и СМT 2018;

- расчет объемов высвобождающейся сейсмической энергии с использованием данных из каталога NEIC 2018 по формуле из работы [Kanamori, Andersen, 1975] и построение по этим данным электронных схем ее площадного распространения в Центральной Азии с шагом $0.5^{\circ}$ по методике авторов;

- построение графиков диссипации сейсмической энергии и глубинных сейсмических разрезов через геораздел и транзитные зоны по методике, разработанной авторами в 2015-2018 гг. [Gatinsky, Prokhorova, 2015; Gatinsky et al., 2018], с определением участков наиболее интенсивной сейсмичности по данным NEIC
2018, глубины гипоцентров и фокальных механизмов по данным СМТ 2018;

- анализ связи высокосейсмичных зон с кинематикой блоков и главных литосферных плит (http://itrf. ign.fr/ITRF_solutions/2014/) и с тектоническими процессами на их границах, проверка идентичности данных о горизонтальных и вертикальных перемещениях блоков по результатам их определений в системе ITRF при сопоставлении с данными о фактических перемещениях вдоль активных разломов и определениями механизмов в гипоцентрах по каталогу СМТ 2018;

- установление соотношения высокосейсмичных зон с геофизическими полями исследуемого региона и с результатами зондирования литосферы (сейсмотомография, GGT 21, INDEPTH) с выявлением глубинных аномалий строения коры и верхней мантии на основе методики, примененной в работе [Gatinsky, Prokhorova, 2014].

\section{3. ГРАНИЦЫ ЦЕНТРАЛЬНОЙ ЧАСТИ ГЕОРАЗДЕЛА И БЛОКОВАЯ СТРУКТУРА ЦЕНТРАЛЬНОЙ АЗИИ}

Четко выраженная центральная часть геораздела 102-104 подтверждается развитием сеймоактивных разломов и многочисленных эпицентров землетрясений (рис. 1). В северной и южной частях эта структура выделяется более условно по отдельным геологическим и тектоническим признакам [Gatinsky et al., 2018]. На территории Северной Монголии геораздел проходит вдоль центриклинального замыкания Хангай-Хентейского синклинория и западного края Амурского блока, или плиты в интерпретации [Zonenshain, Savostin, 1981]. Здесь геораздел выделяется по серии субмеридиональных разломов и границ блоков. Далее к югу с ним совпадает резкое окончание или пережим палеозойских офиолитовых поясов к западу от него и широкое развитие полей кайнозойских базальтов к востоку в Центральной и Южной Монголии. В Северном Китае в пределах геораздела наблюдается виргация каледонских складчатых зон в блоках Джартай и Цилян восточнее массива Цайдам. Отсюда начинается наиболее высокосейсмичная часть рассматриваемой структуры с сейсмоактивными разломами и инструментально замеренными и историческими эпицентрами с магнитудой (M) до 6-8 и более.

Далее к югу геораздел маркируется зоной виргации триасовых складок в зоне индосинид Северо-Западной Сычуани, где они расположены вдоль границы массива Сонпань - погруженного фрагмента платформы Янцзы [Tectonic map..., 1999]. В Южном Китае геораздел отчетливо совпадает с границей складчатых сооружений Восточного Тибета и платформы Янцзы (Южно-Китайской) [Gatinsky et al., 2017a], которая маркируется южной частью протяженного активного разлома Лонгменшан. Южнее рассматриваемая структура совпадает с восточной частью оси (блока) Кам Диан, сложенной магматическими и метаморфическими породами позднепротерозойского фундамента платформы Янцзы. Там развиты активные дислокации 
меридионального простирания и преимущественно левосторонние сдвиги с пулл-апарт бассейнами, а также крупный градиент плотности верхней мантии, мощность которой резко возрастает к востоку [Li etal., 2011]. Геораздел характеризуется на этом участке значительным уменьшением скоростей Р-волн в коре [Wang Ch. et al., 2015].

Современная блоковая структура рассматриваемой части Азии была впервые детально выделена в работе [Gatinsky, Rundquist, 2004]. Авторами учтены последние данные по сейсмоактивным разломам в Центральной Азии и распространению эпицентров инструментально зафиксированных землетрясений по NEIC2018 вместе с данными по историческим землетрясениям [Xu, Deng, 1996]. В результате удалось откорректировать границы блоков Саянского, Бей-Шань, Джартай, Цилян. Был также выделен новый блок Алса на границе Монголии и Китая на месте бывшей восточной части блока Бейшань между блоками Южного Гоби и Джартай (рис. 1, 2). Он представляет собой, по-видимому, остаток какого-то стабильного, возможно докембрийского, массива, поскольку практически асейсмичен.

\section{4. СЕЙСМИЧНОСТЬ ГЕОРАЗДЕЛА И ПРИЛЕГАЮЩИХ ЧАСТЕЙ ТРАНЗИТНЫХ ЗОН}

Наиболее интенсивная сейсмичность характеризует центральную часть геораздела от провинции Внутренняя Монголия на севере до района «Три реки» (Салуин, Меконг, Янцзы) на юге у границы Китая и Мианмар. Анализ новейших китайских инструментальных данных по сейсмичности [Wang Ch. et al., 2015] выявляет более широкое распространение эпицентров сильных (strong), значительных (major) и наиболее интенсивных (great) землетрясений. Фактически полоса их развития расположена между $98-100^{\circ}$ на западе и $105-107^{\circ}$ на востоке (рис. 1, 2, 3), но, тем не менее, это не противоречит принятию площади, ограниченной меридианами 102-104을 в качестве основной оси геораздела.

Механизмы землетрясений в гипоцентрах центральной части геораздела по данным [Wang X. et al., 2015] отвечают преобладанию в северном сегменте (см. рис. 2) левосторонних сдвигов северо-западного простирания с элементами поперечного к ним сжатия. Растяжения приурочены здесь только к северной границе блока Opдос, где они связаны с позднекайнозойским рифтом.

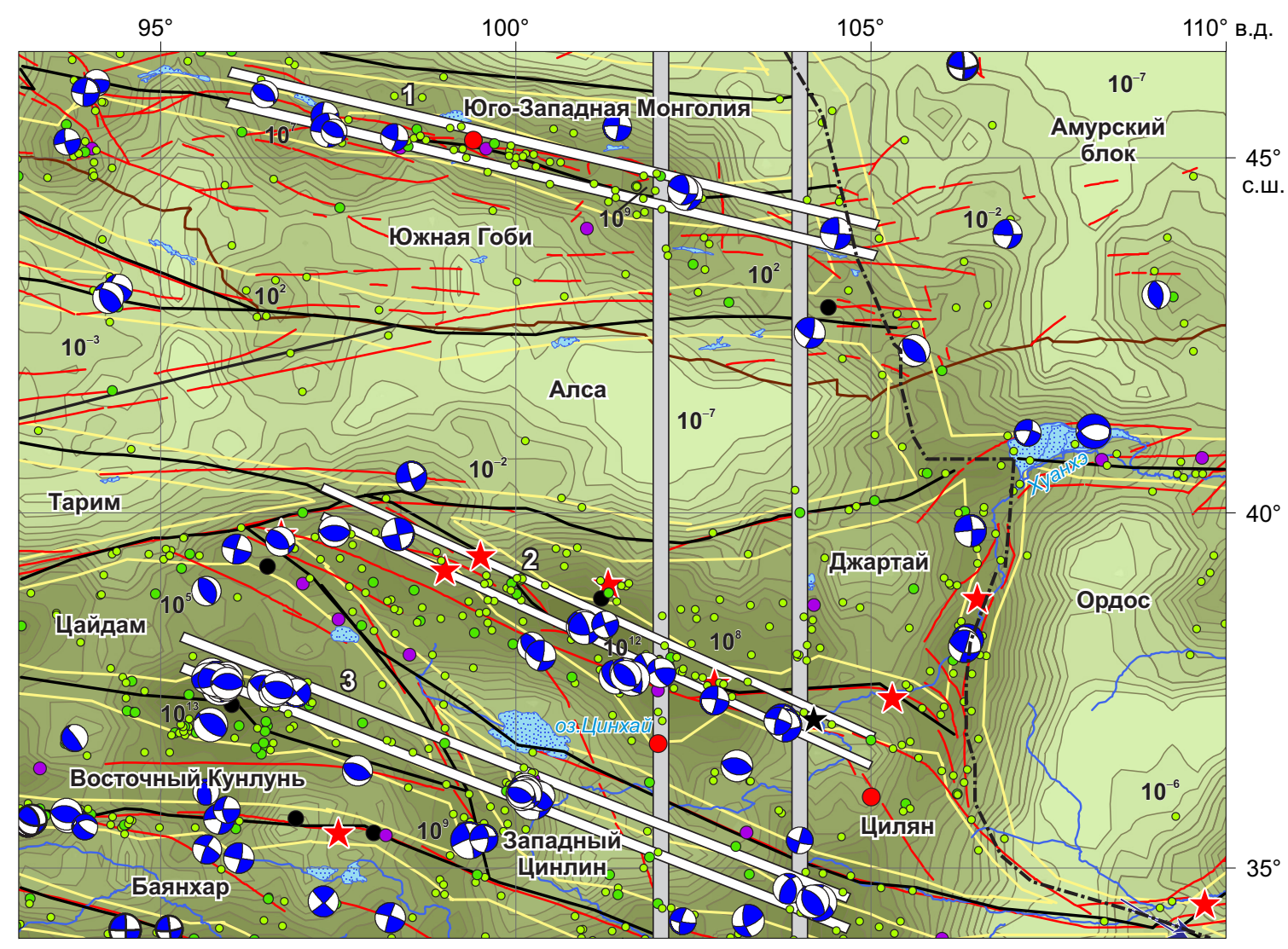

Рис. 2. Схема блокового строения и сейсмичности северного сегмента центральной части геораздела и прилегающих транзитных зон.

Белые линии - границы трансектов через геораздел и его западное крыло с их номерами. Механизмы землетрясений в гипоцентрах показаны по данным СМТ 2018. Остальные обозначения см. на рис. 1. Схема составлена авторами статьи.

Fig. 2. Schematic block structure and seismicity of the northern segment of the geodivider's central part and adjacent transitional zones. The scheme is constructed by the authors of this article.

White lines - boundaries of transects (numbered) crossing the geodivider and its western wing. Earthquake mechanisms in hypocenters are shown according to the CMT 2018 data. See the legend to Fig. 1 for other signs. 


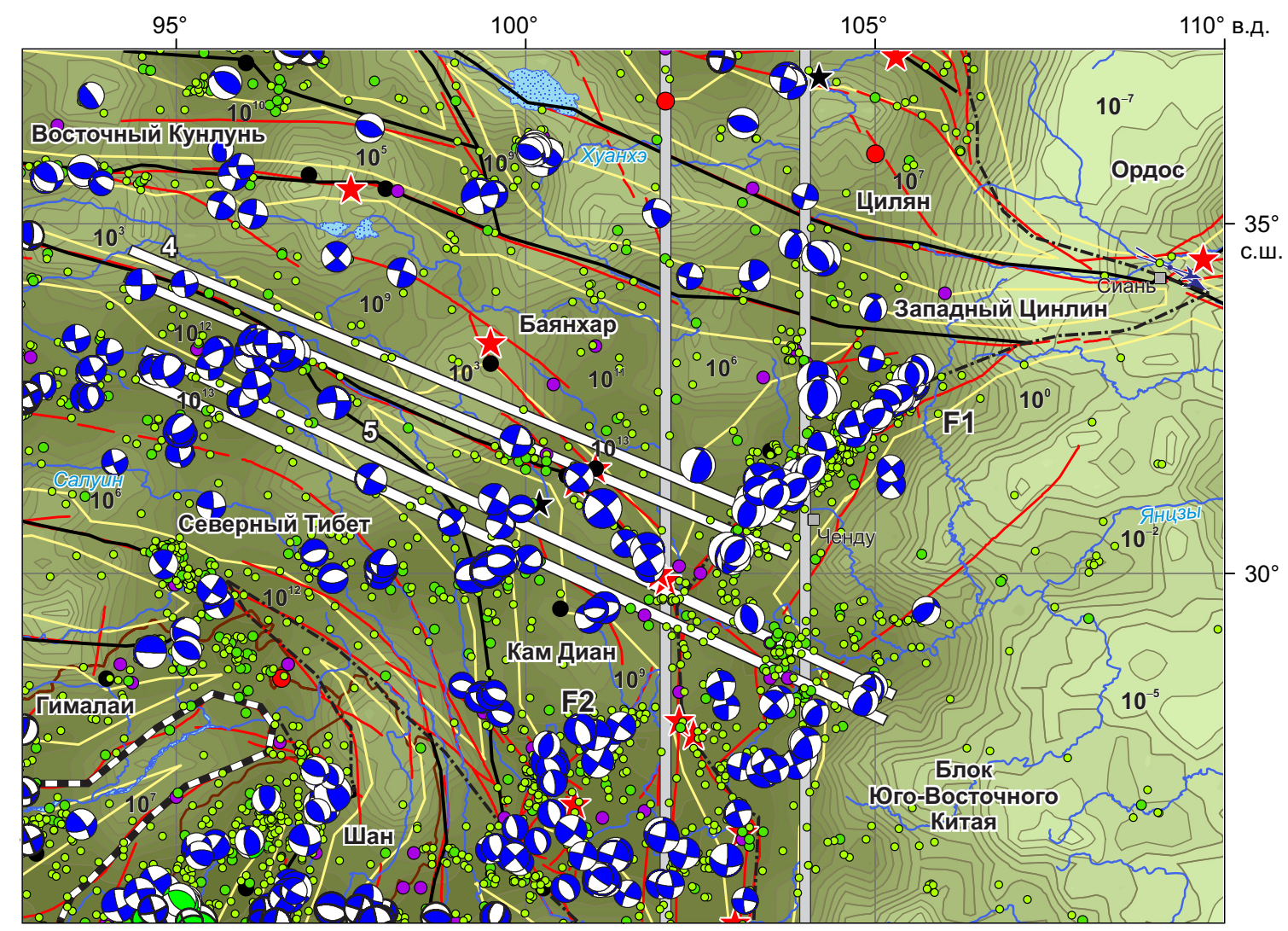

Рис. 3. Схема блокового строения и сейсмичности центрального сегмента центральной части геораздела и прилегающих транзитных зон.

F1 - разлом Лонгменшан, F2 - разлом Лиджианг-Ксиаоджинхе. Остальные обозначения см. на рис. 1 и 2 . Схема составлена авторами статьи.

Fig. 3. Schematic block structure and seismicity of the central segment in the geodivider's central part and adjacent transitional zones. The scheme is constructed by the authors of this article. F1 - Longmenshan fault, F2 - Lijiang- Xiaojinhe fault. See the legends to Fig. 1 and 2 for other signs.

В центральном сегменте центральной части рассматриваемой структуры наиболее широко развиты субмеридиональные и северо-северо-восточные надвиги к востоку, реже к северо-западу, прежде всего, вдоль разлома Лонгменшан (рис. 3, F1). Западнее в пределах геораздела наблюдаются правосторонние сдвиги с элементами субмеридионального растяжения [Gatinsky et al., 2018]. В южном сегменте центральной части геораздела преобладают правосторонние сдвиги северо-восточного простирания (рис. 3) с элементами растяжения на востоке Тибета.

Границы блоков в пределах Центрально-Азиатской транзитной зоны характеризуются повышенной тектонической и сейсмической активностью, приуроченной к относительно узким (50-100 км) межблоковым зонам. Они были впервые выделены в работе [Gatinsky et al., 2009], позднее неоднократно уточнялись [Gatinsky et al., 2011; Gatinsky, Prokhorova, 2014, 2015]. Эти зоны частично близки к «мобильным зонам континентальной литосферы» [Seminskii, 2008] и к «зонам современной деструкции литосферы» [Sherman, Zlogodukhova, 2011]. Глубина гипоцентров в них, как правило, не превышает 10-55 км, что указывает на относительно неглубокое проникновение в литосферу. Редко, например, на Памире и в Бирманских хребтах, она может достигать 80-240 км [Gatinsky, 1986; Gatinsky et al., 2017b], но там гипоцентры совпадают с продолжающейся субдукцией к северу и к востоку слэба Индийской плиты.

Высокосейсмичные межблоковые зоны разделяют блоки Юго-Западной Монголии и Южной Гоби, Джартай и Цилян, Восточный Кунлунь и Цайдам (см. рис. 2, 3). Южнее межблоковые зоны окружают с трех сторон блок Баянхар, а далее к югу - блоки Кам Диан, Шан и Северный Тибет (см. рис. 3 , 4). Магнитуда землетрясений в этих зонах часто достигает 6-7, а в отдельных случаях 8 и более.

Выполненные авторами расчеты объемов высвобождающейся сейсмической энергии показывают ее повышенные значения в пределах центральной части геораздела и на его западном крыле. На севере около Иркутска и к западу от Улан-Батора непосредственно на территории геораздела значения энергии составляют $10^{4}-10^{5}$ Дж, а западнее в Саянском блоке до $10^{8}$ $10^{11}$ Дж (см. рис. 1). На юге блока Юго-Западной Монголии также в пределах геораздела в северном сегменте они возрастают до $10^{12}$ Дж (см. рис. 2). Еще южнее при 


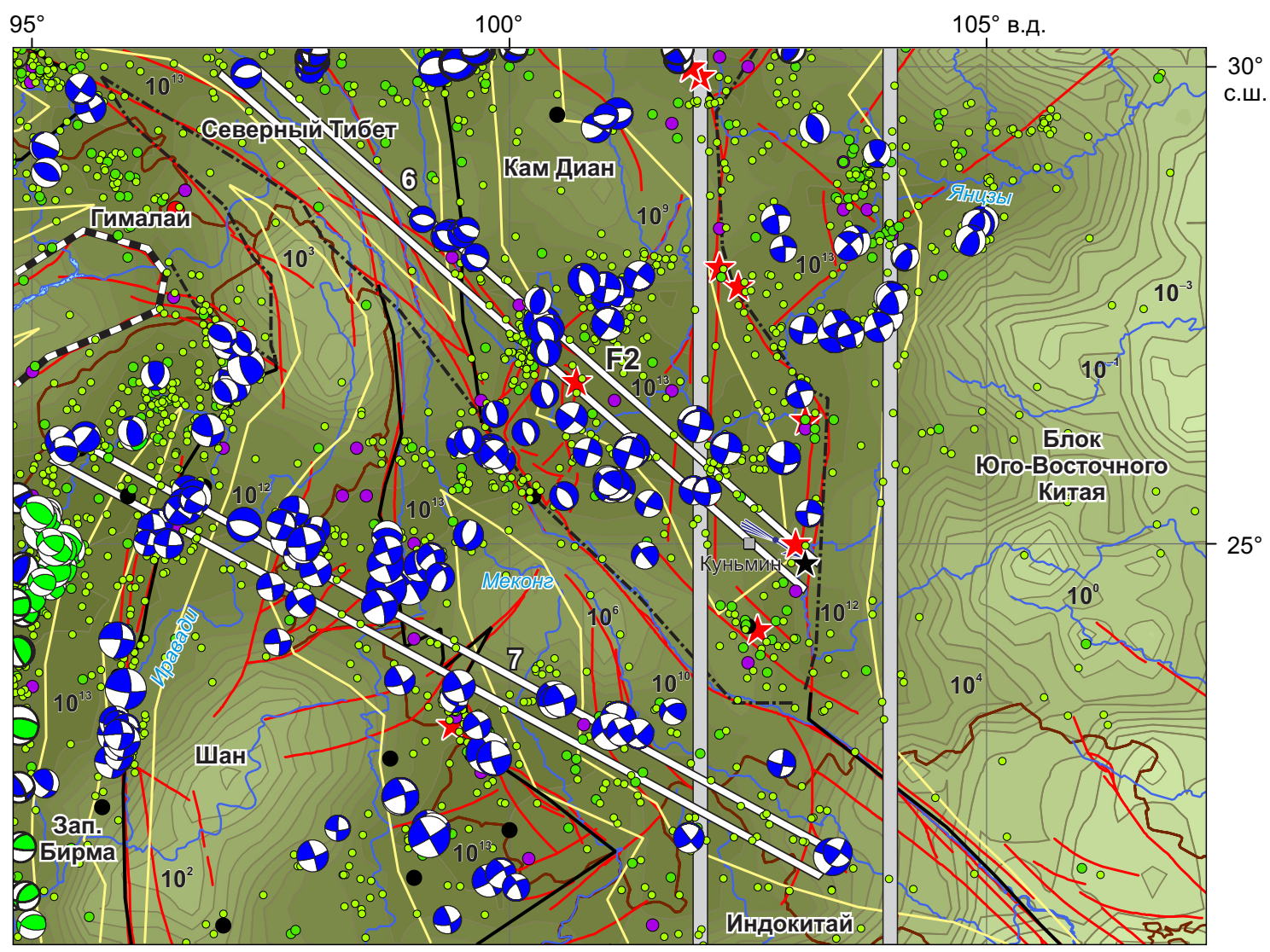

Рис. 4. Схема блокового строения и сейсмичности южного сегмента центральной части геораздела и прилегающих транзитных зон. Условные обозначения см. на рис. 1, 2, 3. Схема составлена авторами статьи.

Fig. 4. Schematic block structure and seismicity of the southern segment in the geodivider's central part and adjacent transitional zones. The scheme is constructed by the authors of this article. See the legends to Fig. 1, 2, 3.

пересечении георазделом блоков Джартай и Цилян значения энергии достигают $10^{11}-10^{12}$ Дж, а западнее в блоке Цайдам увеличиваются до $10^{14}-10^{16}$ Дж, в то время как на востоке, в блоке Ордос, они не превышают $10^{3}$ Дж. В центральном сегменте в пределах принятых нами границ геораздела значения высвобождающейся сейсмической энергии составляют в блоке Западный Цинлин $10^{13}-10^{14}$ Дж (см. рис. 3).

Далее к югу на юго-восточной границе блока Баянхар, пересекаемой георазделом к западу и северо-западу от г. Чэнду, общий объем сейсмической энергии повышается до 9.3·10 ${ }^{16}$ Дж [Gatinsky et al., 2011]. К востоку от г. Чэнду в блоке Юго-Восточного Китая в провинции Сычуань он составляет всего лишь $10^{-2}$ Дж. В южном сегменте (рис. 4) максимальные значения энергии в блоке Кам Диан изменяются от $10^{9}-10^{11}$ Дж на севере до $10^{8}-$ $10^{10}$ Дж на юге в районе г. Кунминь. Такие же величины характеризуют восточную часть блока Северного Тибета и пересечение георазделом южнее северной части Индокитайского блока.

Развитие современной и позднеголоценовой интенсивной сейсмичности характеризует главным образом центральную часть геораздела от южного окончания оз. Байкал до района «Три реки» на границе Китая и Мианмар. Эта часть структуры часто совпадает с межблоковыми зонами, которые были детально изучены в ряде наших предыдущих работ [Gatinsky et al., 2009, 2011]. Данные NEIC 2018 и СMT 2018 дали авторам возможность провести трансекты с глубинными сейсмическими разрезами и графиками диссипации энергии, пересекающие геораздел, блоки и межблоковые зоны к западу от него. В северном трансекте (см. 1 на рис. 2) на востоке в районе границы блоков Амурского и Южной Гоби преобладают относительно неглубокие (812 км) левосторонние сдвиги [Gatinsky et al., 2018]. Гипоцентры с такими же механизмами развиты западнее вместе с надвигами к северо-востоку в пределах геораздела и к западу от него, но объемы высвобождающейся энергии там резко возрастают, а глубина гипоцентров увеличивается до 35-40 км. Сходная картина наблюдается в трансектах 2 и 3 . На востоке второго из них к востоку от геораздела левосторонние сдвиги с незначительно повышенной сейсмичностью приурочены к западной границе блока Ордос (см. рис. 2), где, по данным китайских исследователей, развиты также растяжения. Севернее растяжения на границе Амурского блока и Ордоса связаны с существованием там активной рифтогенной структуры [Tectonic map..., 1999].

Одним из наиболее информативных является трансект 4 в центральном сегменте (см. рис. 3), пересекающий 
юго-восточную часть блока Баянхар в районе эпицентра землетрясения Венчуан. Там развиты надвиги к востоку и юго-востоку, реже к северо-западу с правосдвиговой компонентой на глубине 3-43 км с резким увеличением уровня сейсмической энергии до $10^{13}$ $10^{14}$ Дж как в пределах геораздела, так и непосредственно к северо-востоку от него вдоль разлома Лонгменшан (рис. 3, F1). К западу от геораздела широко распространены устойчивые левосторонние сдвиги на глубине 2-50 км, подтверждающие поворот блока Баянхар, ограниченного с юго-востока разломом F1, по часовой стрелке [Gatinsky et al., 2008, 2011]. В трансекте 5 к западу от геораздела уровень высвобождения сейсмической энергии возрастает до $10^{14}-10^{15}$ Дж. Там преобладают лево- и правосторонние сдвиги на глубине 8-10 км, сменяемые глубже на 20-35 км растяжениями [Gatinsky et al., 2018]. Далее к западу вдоль того же трансекта 5 развиты устойчивые растяжения на глубинах 5-15 км, связанные с субмеридиональными рифтами на востоке Тибета.

В южном сегменте (рис. 4) тот же высокий уровень энергии сохраняется как к западу от геораздела, так и в его пределах. Там развиты лево- и правосторонние сдвиги, реже структуры растяжения на глубинах 0-55 км. На крайнем северо-западе трансекта 7 наиболее глубокий (140 км) гипоцентр, отвечающий сжатию со сдвигом, связан с погружающимся к востоку слэбом в Западно-Бирманской зоне субдукции [Gatinsky, 1986].

\section{5. СВЯЗЬ ПОВЫШЕННОЙ СЕЙСМИЧНОСТИ С МОБИЛЬНОСТЬЮ БЛОКОВ}

Значительное увеличение объема сейсмической энергии на западном крыле геораздела совпадает с повышенной мобильностью блоков и геофизическими аномалиями в литосфере. Рассмотрим это на примерах двух регионов с катастрофическими землетрясениями: юго-восточной части блока Баянхар и северо-западной - Амурского блока. Механизмы в гипоцентрах, по данным СМТ 2018, указывают на левостороннее смещение вдоль зон разломов на границах блока Баянхар, отделяющих его от блоков Западный Цинлин и Восточный Кунлунь на северо-востоке и от Северного Тибета и блока Кам Диан на юго-западе (см. рис. 3). Это предполагает вращение блока Баянхар по часовой стрелке, в результате которого возникает сжатие на его юговосточной границе, подтверждаемое механизмами многочисленных землетрясений, включая Венчуан с М 7.9 в мае 2008 г. [Gatinsky et al., 2008, 2011]. Эта граница проходит вдоль крупного разлома F1, надвигание по которому на блок Юго-Восточного Китая было установлено по геологическим данным [Xu, Deng, 1996].

Полевые исследования непосредственно после землетрясения показали значительное сокращение коры вдоль падающей к северо-западу трещины разлома с надвиганием к юго-востоку одновременно с небольшими правосторонними сдвигами [Liu-Zeng et al., 2009]. Кроме того, отмечается увеличение интенсивности напряжения сжатия в верхней части коры на западе Тибета с резким уменьшением его на востоке в провинции Сычуань [Heidbach et al., 2016].

Общий объем сейсмической энергии, высвобождавшейся на юго-восточной границе блока Баянхар, начиная с 1976 г. до землетрясения 2008 г. составлял $1.1 \cdot 10^{15}$ Дж. Период относительного сейсмического затишья («seismic gap») имел там место, начиная с последнего сильного землетрясения 1973 г. с М 7.4. Медленное накопление сейсмической энергии в течение этого периода релаксировалось катастрофическим событием Венчуан в мае 2008 г., после которого уровень энергии сразу же возрос до 9.3·10 ${ }^{16}$ Дж [Gatinsky et al., 2011]. Отметим, что эта величина близка к уровню энергии наиболее активных западно-тихоокеанских зон субдукции (11.8-15.3·10 ${ }^{16}$ Дж) [Gatinsky, Vladova, 2008].

Экспериментальные векторы GPS в Тибете и ЮгоВосточном Китае подтверждают поворот блока Баянхар по часовой стрелке (см. рис. 1). В этом вращении, по-видимому, участвуют только верхние горизонты коры. По данным Глобального геотрансекта 21 [Yuan et al., 2000] и Программы INDEPTH [Li et al., 2003; Solon et al., 2005], в восточной части блока Баянхар и расположенного южнее блока Северного Тибета на глубине 20-45 км присутствуют низкоскоростные слои и слои повышенной электрической проводимости. Они предположительно отвечают частичному плавлению пород верхней и средней коры. Горячая и пластичная верхняя часть коры Восточного Тибета на границе с холодной, жесткой и более мощной литосферой Юго-Восточного Китая под давлением Индостанского индентора срывается с мантийной и нижнекоровой подложки и движется со скоростью 20-30 мм/год на юго-восток вокруг восточного синтаксиса Гималаев, что подтверждается данными GPS (рис. 5). При этом в Западном Тибете вся литосфера продолжает двигаться на северсеверо-восток в направлении смещения Индостанского индентора [Shen et al., 2005; Gan et al., 2007].

Геораздел продолжается к северу через территорию Китая и Центральной Монголии до юго-западного окончания оз. Байкал, где в 2008 г. произошло землетрясение с М 6.3 у пос. Култук на границе Амурского блока и Северо-Евразийской литосферной плиты. Иркутские исследователи [Miroshnichenko et al., 2007] установили в этом регионе, по данным локальной сети GPS, вращение коры по часовой стрелке с постепенным изменением направления векторов от север-северо-востока и восток-северо-востока на восток и восток-юго-восток. Такая смена направления векторов подтверждается изменением режима напряжений к западу и востоку от юго-западного окончания оз. Байкал. Транспрессивный режим преобладает на западе во впадине Тунка, где по нашим совместно с В.А. Саньковым наблюдениям развиты левосторонние сдвиги со сжатием [Gatinsky et al., 2009; San'kov et al., 2014]. Но восточнее сдвиги замещаются сбросами на флангах Баргузинской депрессии, входящей в состав Байкальской рифтовой системы. Более ранние сдвиги вызвали сейсмические дислокации, смещающие тальвеги правых притоков р. Баргузин. Более 


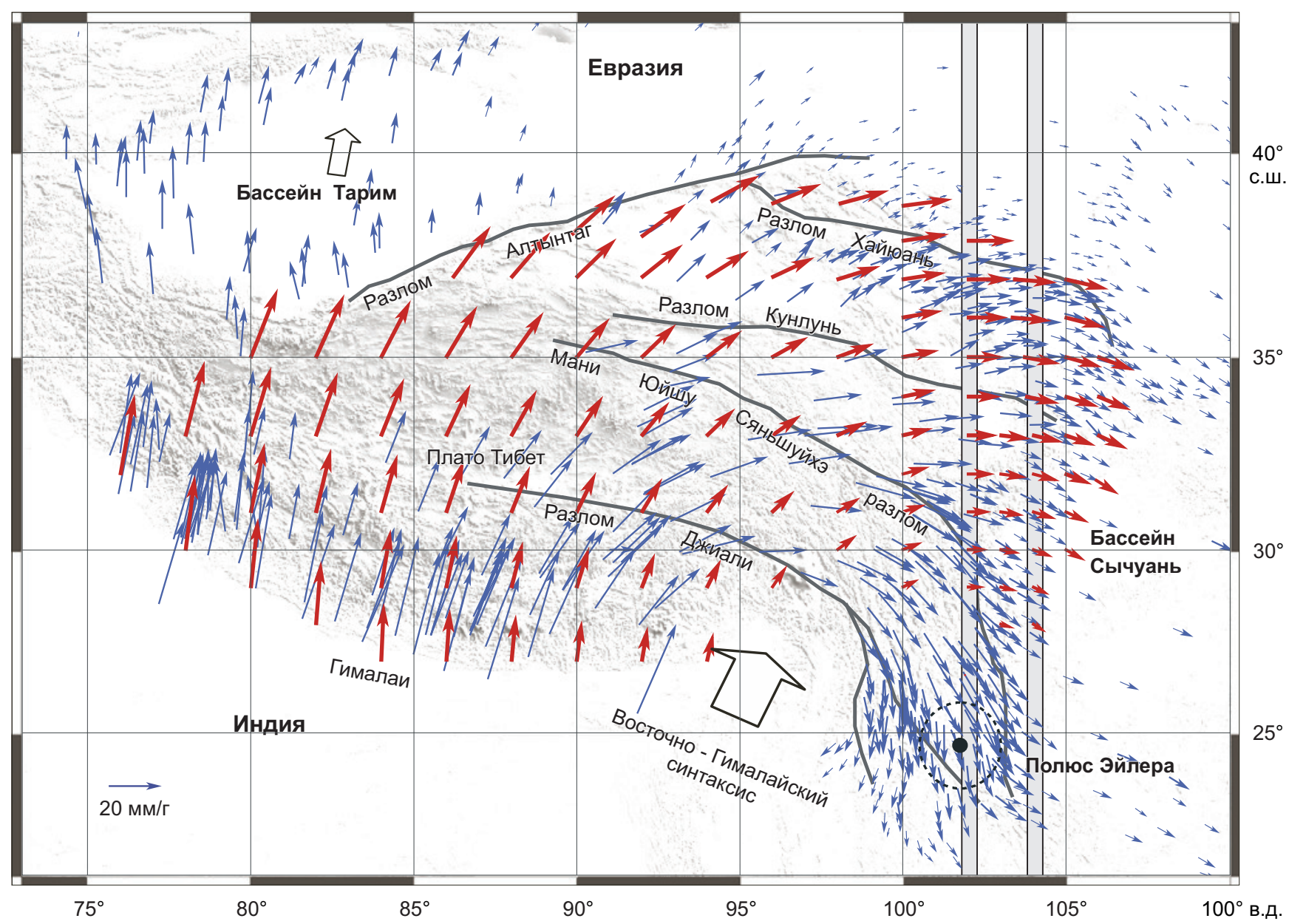

Рис. 5. Карта поля наблюдаемых скоростей GPS (синие стрелки) вокруг плато Тибет относительно стабильной Евразии и поля рассчитанного устойчивого вращения (красные стрелки) вместе с Эйлеровым вектором плато.

Полюс Эйлера расположен вблизи юго-восточного угла плато в пределах геораздела $102-104^{\circ}$ с эллипсом 95\%-ной доверительности. Более толстые черные сплошные линии обозначают главные активные разломы [Gan et al., 2007]. На этом и рис. 6, 7, 8 даны границы геораздела.

Fig. 5. Map showing the observed GPS velocity field (blue arrows) around the Tibetan Plateau relative to the stable Eurasia and the calculated rigid rotation velocity field (red arrows) with the Euler vector of the plateau.

The Euler pole is located near the southeastern corner of the plateau within the $102-104^{\circ}$ geodivider (95 \% confidence ellipse). Thick black solid lines indicate principal active faults [Gan et al., 2007]. The geodivider boundaries are shown in this figure and in Fig. 6, 7, 8.

поздние сбросы нарушают эти сдвиги и пересекают все породы от палеозойских гранитов до четвертичного аллювия.

\section{6. СООТНОШЕНИЕ ГЕОДИНАМИКИ ГЕОРАЗДЕЛА 102-104 В.Д. И СМЕЖНЫХ ТРАНЗИТНЫХ ЗОН С ГЛУБИННЫМ СТРОЕНИЕМ ЛИТОСФЕРЫ}

Блоки в центральной части геораздела и на востоке его западного крыла в магнитном поле представлены слабоотрицательными или слабоположительными аномалиями $(-30 \ldots+10$ nT). Крупные разломы на их границах выделяются более высокими полосовыми позитивными аномалиями до +20 ...+50 nT [Korhonen et al., 2007]. Большая часть Центральной Азии характеризуется отрицательными гравитационными аномалиями в редукции Буге до -50...-150 mGal [Bonvalot et al., 2012]. Высокие значения негативных аномалий отвечают резкому возрастанию мощности коры к западу от 35-40 км до 45-70 км. Наибольшие значения коэффициента Пуассона приходятся на восточные границы блоков Баянхар, Кам Диан и на юг западной границы Ордоса (рис. 6), совпадая с повышенными напряжениями в зонах надвигов к востоку на этих границах [Wang Ch. et al., 2015].

Территория геораздела характеризуется на многих участках выокими значениями теплового потока (ТП), начиная от юга Сибири до северной части Индокитайского п-ова (рис. 7). Представляет интерес проследить изменения значений ТП вместе с объемами высвобождающейся сейсмической энергии и векторами GPS в пределах геораздела, к западу и востоку от него. В районе юго-западного окончания рифта Байкала ТП составляет 54-60 мВт/м², объемы энергии до $10^{6}-10^{7}$ Дж, азимут вектора GPS $105.6^{\circ}$ ЮВ. Западнее, в районе рифта Хубсугул на севере Монголии, ТП возрастает до 


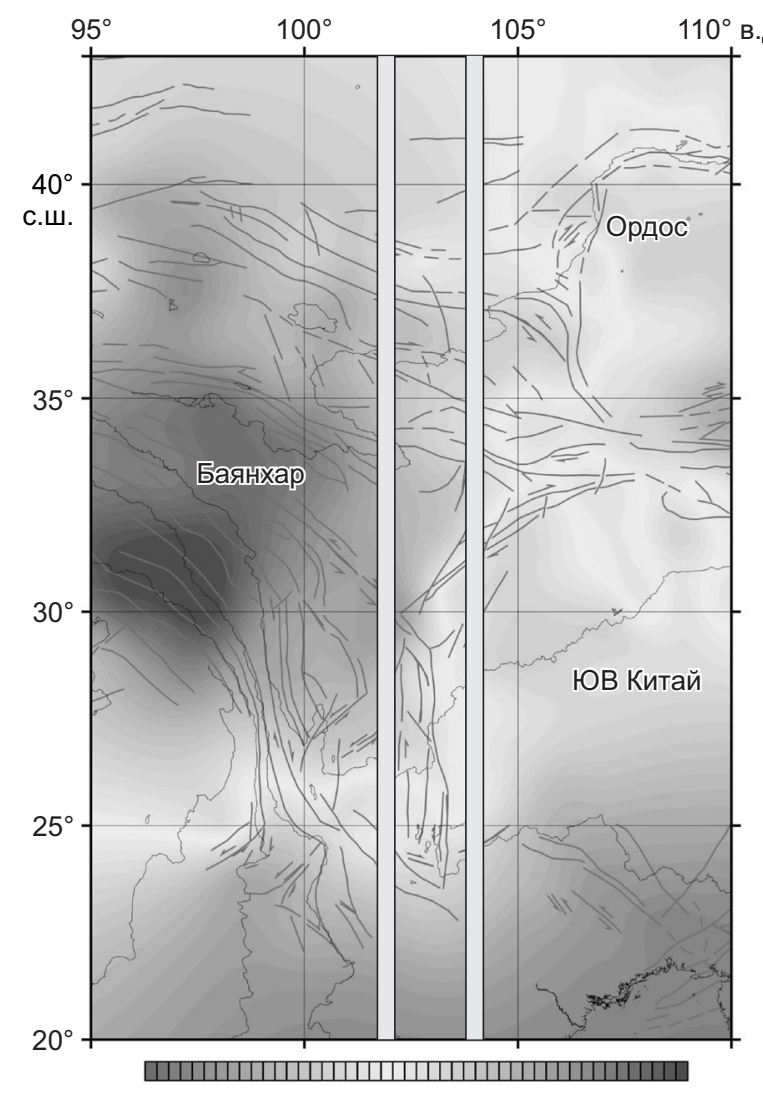

$\begin{array}{lllllllllll}27 & 31 & 35 & 39 & 43 & 47 & 51 & 55 & 59 & 63 & 67\end{array}$

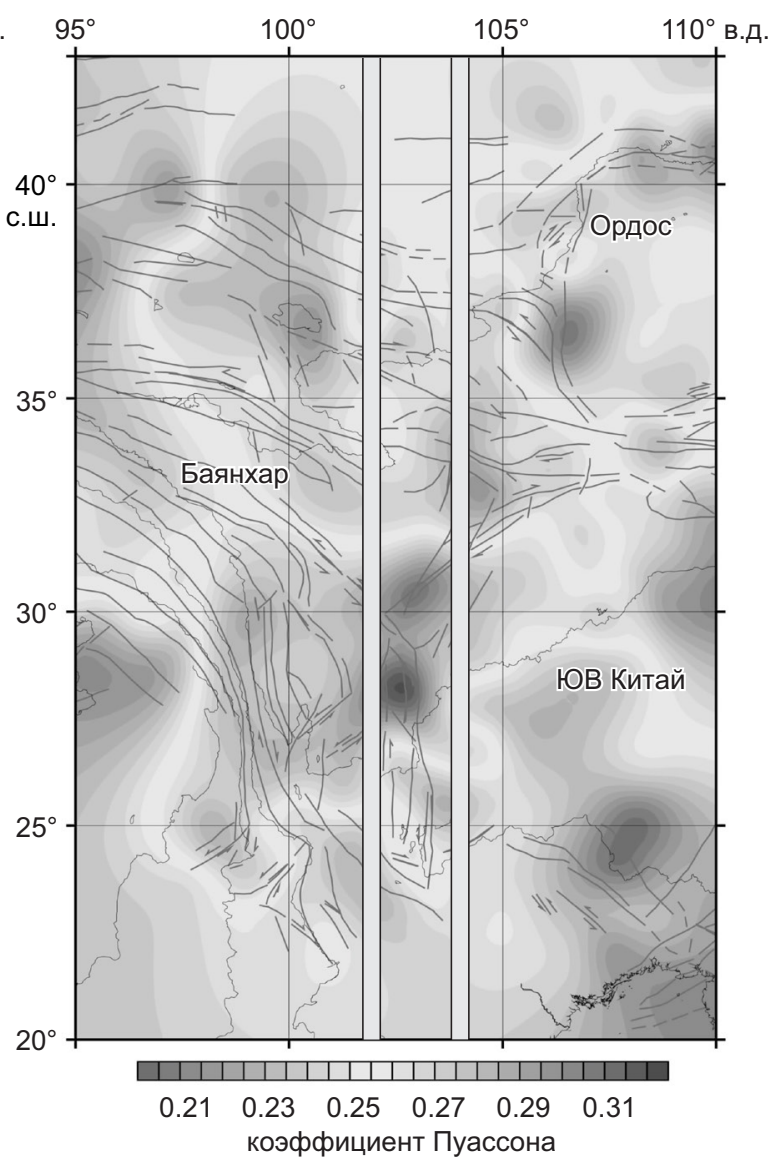

Рис. 6. Мощность коры (слева) и распределение коэффициента Пуассона (отношение элементарной поперечной деформации к продольной деформации в теле, испытывающем продольную нагрузку, не превосходящую предела упругости) в пределах геораздела [Wang Ch. et al., 2015].

Fig. 6. Crust thickness (left) and Poisson's ratio distribution (right) within the geodivider [Wang Ch. et al., 2015].

78-140 мВт/м², объемы энергии до $10^{8}-10^{11}$ Дж. Этот район находится почти в центре предполагаемого восходящего мантийного плюма, вершина которого фиксируется на глубинах 150-100 км [Gatinsky, Prokhorova, 2015].

Восточнее, на севере Амурского блока, ТП равен 6584, а в центральной части рифта Байкала достигает 96140 мВт/м². Южнее, к западу от г. Улан-Батора, объем сейсмической энергии в пределах геораздела составляет $10^{8}-10^{10}$ Дж, М событий до 6.99-7.99. Западнее, в блоке Хангай, объем энергии увеличивается до $10^{11}$ Дж, М землетрясений до $\geq 8$. На востоке, в районе Улан-Батора, ТП равен 71-86 мВт/м², объем энергии уменьшается до $10^{-1}-10^{-2}$ Дж, азимут вектора GPS составляет 106.86-108.00 ЮB [San'kov et al., 2015]. Далее на юг в блоке Юго-Западной Монголии, объем энергии в георазделе равен $10^{8}$ Дж, западнее до $10^{9}-10^{10}$ Дж. Еще южнее, в блоке Цилян к востоку от оз. Цинхай (Кукунор), ТП составляет 76-87 мВт/м², объем энергии $10^{11}-10^{12}$ Дж, М до $\geq 8$. Западнее, в блоках Цайдам и Восточный Кунлунь, ТП резко уменьшается до 40-47 мВт / ${ }^{2}$ одновременно с ростом уровня энергии до $10^{12}-10^{16}$ Дж. На востоке в районе г. Сиань ТП равен 64-67 мВт/м², азимут вектора составляет $108.43^{\circ}$ ЮВ.
В центральном секторе, на юго-востоке блока Баянхар, ТП достигает 66-71 мВт/м², объем энергии $10^{8}-$ $10^{13}$ Дж, $\mathrm{M} \geq 8$. Восточнее, в блоке Юго-Восточного Китая, ТП увеличивается до 68-124 мВт/м², объем энергии падает до $10^{10}$ Дж, азимут вектора GPS у г. Ухань (Uhan) равен $109.72^{\circ}$ ЮВ. В южном секторе геораздела, у г. Кунминь (Kunmin), ТП составляет 77-92 мВт/м², объемы энергии достигают $10^{15}-10^{16}$ Дж, азимут вектора еще более отклоняется к югу до $120.11^{\circ}$ ЮВ. Восточнее, в блоке Юго-Восточного Китая, ТП равен 60-71 мВт/м², объем высвобождающейся сейсмической энергии уменьшается до $10^{3}-10^{10}$ Дж. Отметим, что большинство полей повышенного ТП [Tan, Shen, 2008; The Global Heat Flow ..., 2011; Duchkov et al., 2012] совпадает с проекциями контуров замедления S-волн до 4.2-4.25 км/с (рис. 7) на глубинах 100-300 км [Kozhevnikov, Yanovskaya, 2005].

\section{7. ОБСУЖДЕНИЕ РЕЗУЛЬТАТОВ}

Геораздел 102-104 начал формироваться в Центральной Азии, скорее всего, не позднее возникновения активной фазы коллизии Индии и Евразии около 20 млн лет назад и продолжает свое формирование до настоящего времени, что подтверждается сильными 


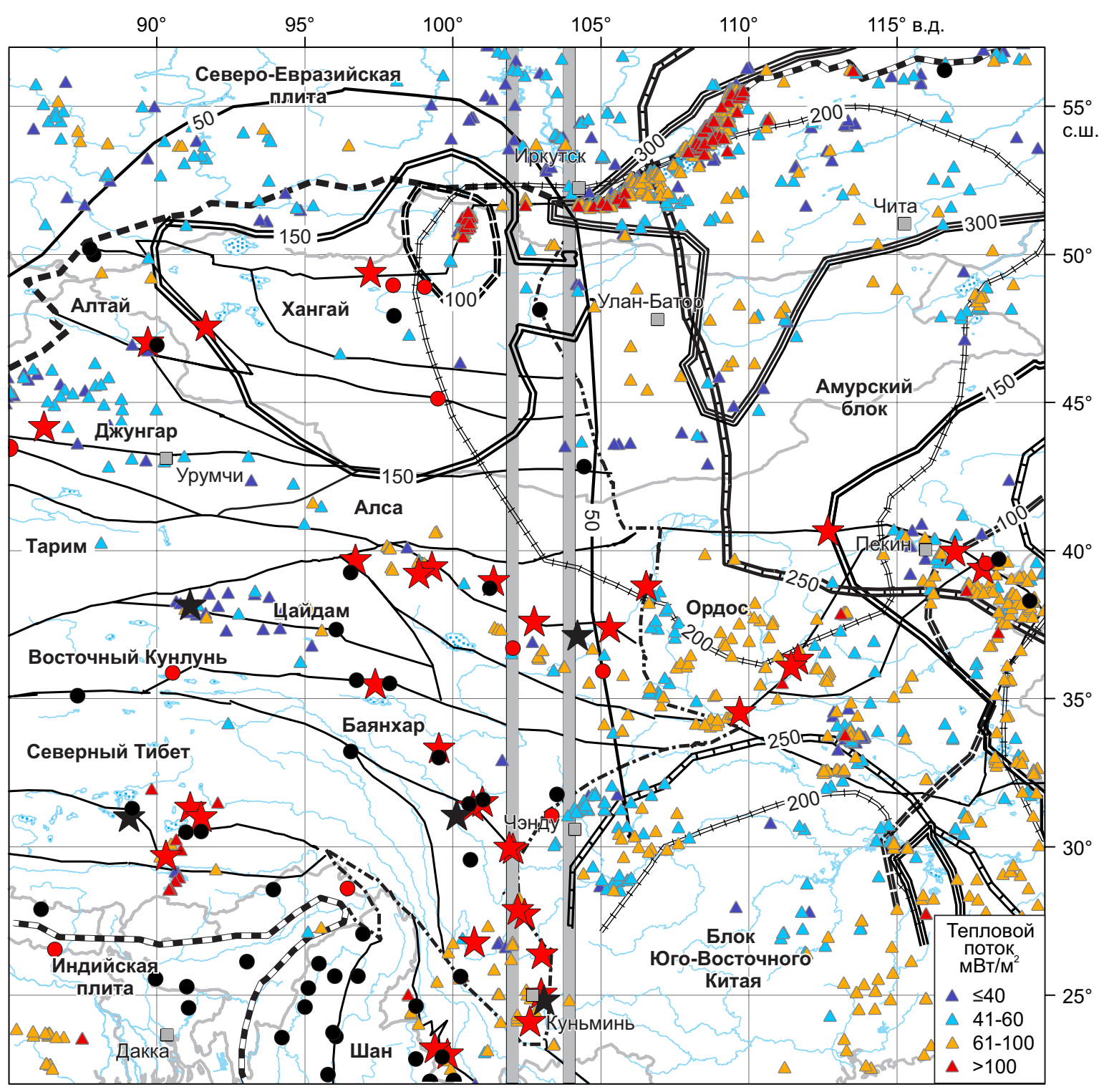

Рис. 7. Схема блоковой структуры Центральной Азии со значениями ТП [Tan, Shen, 2008; Lysak, 2009; The Global Heat-Flow..., 2011; Duchkov et al., 2012].

Названия неподписанных блоков см. на рис. 1. Линиями различного типа показаны проекции на поверхность Земли контуров замедления S-волн до 4.20-4.25 км/с на глубинах 100, 150, 200, 250 и 300 км [Kozhevnikov, Yanovskaya, 2005]. Cxeма составлена авторами статьи.

Fig. 7. Schematic block structure of Central Asia and heat flow values [Tan, Shen, 2008; Lysak, 2009; The Global Heat-Flow..., 2011; Duchkov et al., 2012].

The scheme is consolidated by the authors of this article. The names of the numbered blocks are given in the legend to Fig. 1 . The scheme shows the Earth surface projections of S-wave slowing contours (to $4.2-4.25 \mathrm{~km} / \mathrm{sec}$ ) at the depths of 100, 150, 200, 250, and $300 \mathrm{~km}$ [Kozhevnikov, Yanovskaya, 2005].

землетрясениями в последние годы в его границах (Венчуан и другие). Эта фаза континентального столкновения привела к образованию современной ЦентральноАзиатской транзитной зоны с ее разломно-блоковой структурой и к резкому возрастанию уровня высвобождения сейсмической энергии в пределах центральной части геораздела и к западу от него. Если в центральном и южном сегментах этой части он во многом совпадает с границами блоков и крупными субмеридиональными разломами (Лонгменшан и другие), то севернее эта структура пересекает большинство геологических границ и выделяется в основном по повышенному уровню сейсмичности, ТП и аномалиям глубинного строения, включая мантийную анизотропию.

Отметим, что по результатам анализа, выполненно го иркутскими геофизиками, направления анизотропии $P$ и $S$-волн доказывают единую деформацию верхнемантийной и коровой литосферы в пределах большей северной части Центральной Азии [San'kov et al., 2011], в том числе в северной половине центральной части 
геораздела. Это позволяет предполагать существование источника современной геодинамической активности в подлитосферной мантии, что подтверждается развитием мантийных плюмов. Один из таких плюмов может быть выделен под блоками Хангай и Саяны на глубине 100-150 км (рис. 7), где мощность литосферы уменьшается до 70-50 км и температура на основе корреляции изотопов ${ }^{3} \mathrm{He} /{ }^{4} \mathrm{He}$ может составлять под ней 1000-1200 ${ }^{\circ} \mathrm{C}$ [Lysak, 2009; Duchkov et al., 2010].

Проведенный анализ различных параметров сейсмичности, ТП, мобильности блоков и глубинных аномалий под ними позволяет сделать следующие выводы. Уровень интенсивности сейсмичности в целом возрастает с востока на запад с максимальными значениями в пределах геораздела и к западу от него в Центрально-Азиатской транзитной зоне. Величины ТП растут в противоположном направлении с запада на восток, достигая максимальных значений в георазделе и в Восточно-Азиатской транзитной зоне. Примерно в том же направлении с отклонением к северо-востоку возрастает глубина замедления скоростей $S$-волн до 4.24.25 км/с в верхней мантии. Азимуты векторов GPS изменяются с запада на восток от направления к северовостоку и восток-северо-восток южнее на восточные и юго-восточные и все больше отклоняются к югу.

Данные о мантийной анизотропии по наблюдениям за расщеплением сейсмических волн и по результатам, полученным на постоянных станциях, наряду с определением направления поляризации быстрых $P$-волн и времени задержки прихода быстрых и медленных $S$-волн, позволяют воссоздать анизотропную картину литосферы в пределах геораздела (рис. 8). На севере анизотропия связана с литосферными деформациями [Chang et al., 2016]. Быстрые волны направлены на северо-западюго-восток на северо-восточной окраине Тибетского плато, в блоке Алса, на западной и северной окраинах Ордоса. В блоке Цинлин их простирания близки к широтным, а под Ордосом они почти меридиональные на севере, изменяющиеся на субширотные на юге.

Время запаздывания волн внутри Ордоса меньше, чем в других структурах. Наибольшее время запаздывания установлено на соединении северо-восточного края Тибетского плато с блоками Алса и Ордос. Следовательно, оно уменьшается на стабильных структурах по сравнению с активными. Анализ соответствия направления быстрых волн двойного лучепреломления и предсказанной ориентации, рассчитанной по полю поверхностной деформации, указывает на согласованность поверхностной и мантийной деформации на северо-восточной окраине Тибета, под блоком Алса, на западной и северной окраинах Ордоса. Эти результаты предполагают вертикально согласованную деформацию всей литосферы, играющую главную роль в наблюдаемой сейсмической анизотропии под северной частью геораздела.

На юге геораздел проходит вдоль восточного края Тибетского плато. Здесь половина землетрясений сильные (М 6.0-6.9) и значительные (М 7.0-7.9), единичные - наиболее интенсивные ( $\mathrm{M} \geq 8.0)$. Наблюдения за расщеплением $S$-волн из насыщенного массива сейсмической информации и данных постоянных сейсмических станций позволяют оценить изменения в динамике центрального и южного сегментов геораздела [Chang et al., 2015]. Направление поляризации является субмеридиональным на севере и изменяется почти на широтное на юге. Среднее время задержки прихода волн на станциях на севере 0.8 с, на юге 1.1 с. На юге наблюдаемая анизотропия связана с потоком вещества астеносферной мантии под тонкой литосферой Тибета. Приведенные выше сведения по анизотропии южного сегмента геораздела наряду с данными GPS отвечают деламинации и разрыву разогретой и относительно тонкой литосферы Юго-Восточного Тибета [Hu et al., 2012] и движению ее слоев в разных направлениях (см. рис. 5).

К западу от геораздела в условиях режима транспрессии развиты надвиги и крупные сдвиги со сжатием, северные и северо-восточные направления векторов GPS, а скорости с юга на север изменяются от 50 до 2325 мм/год. К востоку от него преобладает тектонический режим транстенсии с растяжениями в Байкальском рифте и во всей Байкальской рифтовой системе, вокруг Ордоса и сдвигами с растяжением внутри блоков Юго-Восточного Китая и Японско-Корейского [Gatinsky et al., 2017a]. Векторы направлены здесь преимущественно на 106-121 ЮВ со скоростями 26-35 мм/год (см. рис. 1). Такая смена геокинематики предположительно связана с действием мантийных потоков, возникающих под влиянием глубокопогруженного тихоокеанского субдукционного слэба, и с предполагаемым поднятием мантийных плюмов под Байкалом и Северной Монголией [Gatinsky et al., 2011].

К близкому выводу о различии геодинамических режимов по обе стороны от геораздела приходят авторы работы [Bushenkova et al., 2018], рассматривающие его глубинное строение в качестве субмеридионально протяженного нисходящего потока в конвективной структуре верхней мантии региона. По их мнению, он возник, вероятно, в результате суперпозиции неоднородностей мощности литосферы и представляет собой преграду на пути распространения проявляющихся в сейсмическом режиме активных геодинамических процессов, вызванных коллизией. Но, скорее всего, эта преграда была относительной, поскольку влияние процессов коллизии отмечается восточнее геораздела, например в ЮгоВосточной Монголии [Parfeevets, San'kov, 2018].

По данным сейсмотомографии тихоокеанский слэб выполаживается вблизи побережья Азии на глубинах около 600 км и продолжается далее на запад более чем на 1500 км до геораздела 102-104 [Huang, Zhao, 2009]. Это приводит к разогреву литосферы с повышением ТП, развитием позднекайнозойского внутриконтинентального вулканизма и рифтовых бассейнов в Восточно-Азиатской зоне. Авторы, как и ряд китайских исследователей, связывают такой разогрев литосферы до $100 \mathrm{mBт} / \mathrm{M}^{2}$ и более с влиянием глубокопогруженного 


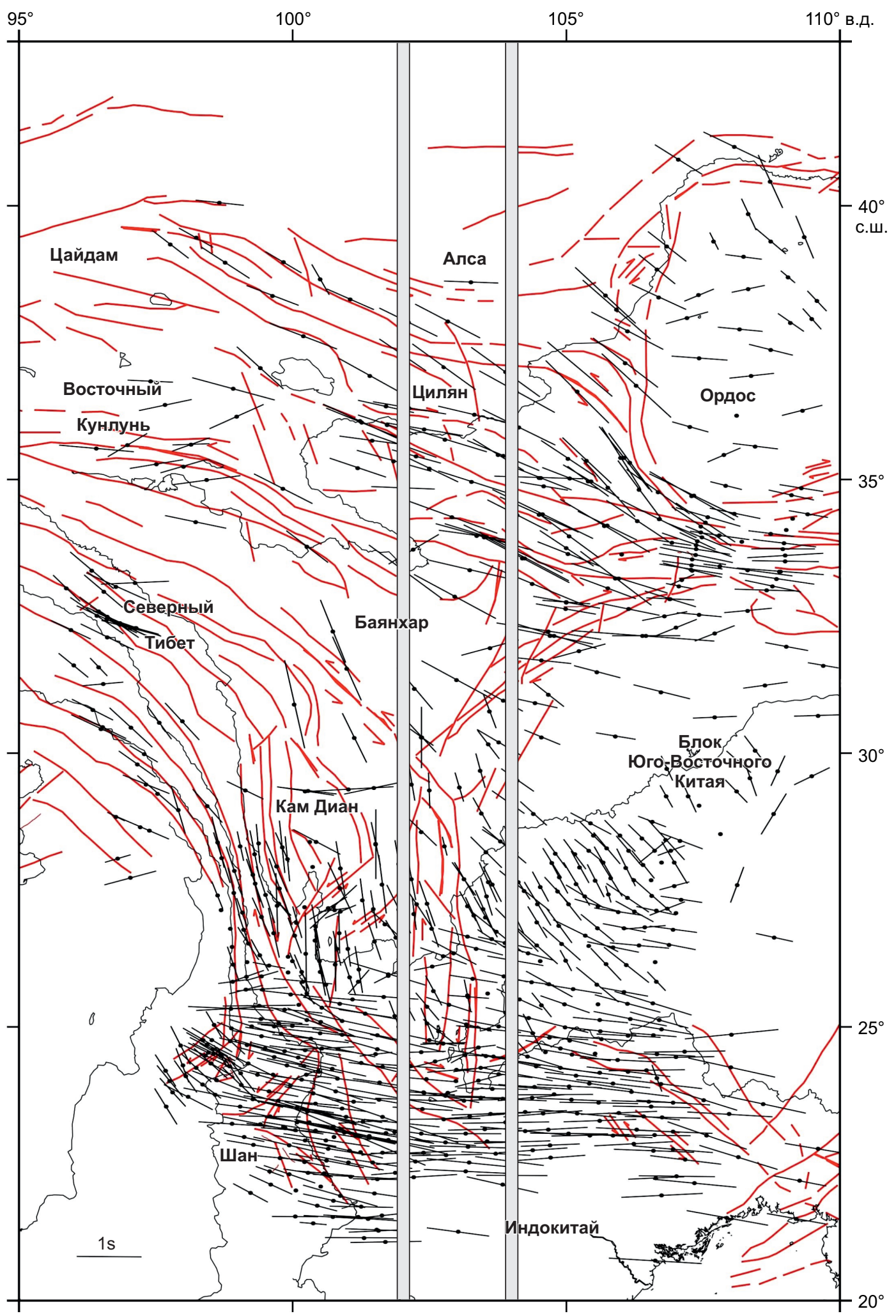

Рис. 8. Распределение значений анизотропии верхней мантии в пределах геораздела и примыкающих к нему частей транзитных зон [Wang Ch. et al., 2015].

Направление и длина линий с точками отвечают направлению быстрых S-волн и задержке времени расщепления медленных SKS волн, соответственно. Красные линии - разломы, часто со стрелками, отвечающими направлению перемещения их крыльев.

Fig. 8. Distribution of the upper mantle anisotropy values within the geodivider's central part and adjacent transitional zones [Wang Ch. et al., 2015].

The directions and lengths of dotted black lines correspond to the directions of fast S-waves and the splitting time delays of slow SKSwaves, respectively. Red lines - faults (displacement directions are marked by arrows). 
слэба под Восточной Азией и его стагнацией - застойностью, инерцией при постепенном отмирании.

Группа геофизиков исследовала продолжение активного под Японией и Японским морем тихоокеанского слэба в пределах прилегающей территории КНДР и Северо-Восточного Китая по результатам анализа томографии $P$ - и $S$-волн и телесейсмической томографии [Chen et al., 2017]. На расстоянии около 1000-1100 км от Японского желоба слэб четко прослеживается по гипоцентрам землетрясений до глубины 500-600 км с ускорением волн до 4-6 \%, погружаясь в мантию в наклонной зоне шириной от 70-50 до 100-150 км. Дальше он становится квазигоризонтальным и продолжается еще на 1000 км к западу под территорией СевероВосточного Китая, сохраняя примерно те же показатели $\mathrm{dVp}$ и dVs, но уже без гипоцентров. На всем протяжении слэб подстилается мантией с замедлением волн от 0 до $-4 . . .-6 \%$ и перекрывается мантийным клином с замедлением волн от 0 до $-2 \%$, локально ближе к поверхности до $-3 . . .4 \%$.

Китайские исследователи связывают формирование вулканических очагов в верхах мантии и коре и извержение активных голоценовых вулканов в пограничных районах КНДР и Китая с поднятием горячего и влажного материала к поверхности при дегидратации глубокопогруженного слэба [Chen et al., 2017]. Одним из источников этого вулканизма могут служить также флюиды, высвобождающиеся благодаря глубоким разломам над интенсивно циркулирующими мантийными потоками вблизи слэба. Замедления $S$-волн в верхах верхней мантии до $-4 \ldots$.. 6 на глубинах от 100 до 200 км отмечаются также к юго-востоку и юго-западу от оз. Байкал [Legendre et al., 2015] и до 4.1-4.3 км/с под рифтом Байкала, Хангаем и Северо-Восточным Китаем на глубинах от 100 до 300 км (см. рис. 7) [Kozhevnikov, Yanovskaya, 2005]. В большинстве этих районов известны излияния голоценовых щелочных базальтов.

Пластичный поток материала Тибетского плато к востоку [Gan et al., 2007; Hu et al., 2012] и повышенная проницаемость латеральных границ на разломах Лонгменшан, Лиджианг-Ксиаоджинхе (см. рис. 3, 4, F1, F2) и других способствуют высвобождению сейсмической энергии. Таким образом, поле напряжений в литосфере центрального и южного сегментов геораздела контролируется совместно сжатием со стороны Индийской плиты к северо-востоку и север-северо-востоку и движением к юго-востоку материала средней и верхней коры Тибетского плато, который выжимается вдоль крупных сдвигов. Отметим, что предположение о восточной экструзии тибетской литосферы впервые было высказано в работе [Molnar, Tapponier, 1975].

\section{8. ЗАКЛЮЧЕНИЕ}

В предыдущих разделах работы установлена связь с границами ряда блоков гравитационных аномалий, отражающих повышение мощности коры в центральной части геораздела, в том числе на границах блоков Тибета и Юго-Восточного Китая. Эта же часть геораздела характеризуется наиболее высокими значениями коэффициента Пуассона, отвечающими увеличению поперечного сжатия, и проекциями замедления $Р$-волн на различных глубинах. Установленное возрастание значений ТП с запада на восток в пределах Восточно-Азиатской транзитной зоны наряду с преобладанием в этой зоне структур растяжения предположительно может быть связано с продолжением и распадом под этой территорией глубокопогруженного тихоокеанского слэба. В то же время к западу от геораздела наблюдается увеличение уровня высвобождающейся сейсмической энергии с максимальными магнитудами в эпицентрах. Здесь господствуют надвиги и протяженные сдвиги с элементами сжатия.

По данным о сейсмической анизотропии воссоздается структура литосферы в центральной части геораздела. На севере предполагается вертикально согласованная единая деформация всей литосферы, на юге наблюдаемая анизотропия связана с потоком вещества астеносферной мантии к юго-востоку под тонкой литосферой Тибета, в которой происходит деламинация с разнонаправленным горизонтальным перемещением ее различных слоев. Приведенные данные подтверждают связь геодинамики рассматриваемой части Центральной Азии с аномалиями глубинного строения литосферы и подстилающей верхней мантии, что приводит к различию геодинамических режимов к западу и востоку от геораздела $102-104^{\circ}$ в.д.

\section{9. БЛАГОДАРНОСТИ}

Авторы признательны В.А. Санькову за приглашение кучастию в совместных полевых исследованиях в Забайкалье в 2008 г. и за неоднократное конструктивное обсуждение затронутых в настоящей работе проблем современной геодинамики Центральной Азии. Большую помощь в решении этих проблем оказали статьи и монографии профессора С.И. Шермана, посвященные сейсмичности, сейсмическим поясам и зонам, сейсмоактивным разломам и тектонофизическому моделированию современной геодинамической активности рассматриваемого региона, как и имевший место личный обмен мнениями с ним в этой области.

\section{0. ЛИТЕРАТУРА / REFERENCES}

Bonvalot S., Balmino G., Briais A., Kuhn M., Peyrefitte A., Vales N., Biancale R., Gabalda G., Moreaux G., Reinquin F., Sarrailh M., 2012. World Gravity Map. Scale 1:50000000. BGI-CGMW-CNES-IRD, Paris.

Bushenkova N.A., Kuchai O.A., Chervov V.V., 2018. Submeridional Boundary Zone in Asia: Seismicity, Lithosphere Structure, and the Distribution of Convective Flows in the Upper Mantle. Geodynamics \& Tectonophysics 9 (3), 10071023 (in Russian) [Бушенкова Н.А., Кучай О.А., Червов В.В. Субмеридиональная пограничная зона в Азии: сейсмичность, структура литосферы и распределение конвективных потоков в верхней мантии // Геодинамика и тектонофизика. 2018. Т. 9. № 3. С. 1007-1023]. https:// doi.org/10.5800/GT-2018-9-3-0381. 
Chang L.-J., Ding Z.-F., Wang Ch.-Yo., 2015. Upper Mantle Anisotropy beneath the Southern Segment of North-South Tectonic Belt, China. Chinese Journal of Geophysics - Chinese Edition 58 (11), 4052-4067. https://doi.org/10.6038/cjg 20151114.

Chang L.-J., Ding Z.-F., Wang Ch.-Yo., 2016. Upper Mantle Anisotropy beneath the Northern Segment of the NorthSouth Tectonic Belt in China. Chinese Journal of Geophysics - Chinese Edition 59 (11), 4035-4047. https://doi. org/10.6038/cjg20161109.

Chen Ch., Zhao D., Tian Y., Wu S., Hasegawa A., Lei J., Park J.-H., Kang I.-B., 2017. Mantle Transition Zone, Stagnant Slab and Interpolate Volcanism in Northeast Asia. Geophysical Journal International 209, 68-85. https://doi.org/ 10.1093/gji/ggw491.

Duchkov A.D., Rychkova K.M., Lebedev V.I., Kamensky I.L., Sokolova L.S., 2010. Estimation of Heat Flow in Tuva from Data on Helium Isotopes in Thermal Mineral Springs. Russian Geology and Geophysics 51 (2), 209-219. http://doi. org/10.1016/j.rgg.2009.12.023.

Duchkov A.D., Zheleznyak M.N., Ayunov D.E., Veselov O.V., Sokolova L.S., Kazantsev S.A., Gornov P.Yu., Dobretsov N.N., Boldyrev I.I., Pchelnikov D.V., Dobretsov A.N., 2012. Geothermal Atlas of Siberia and Far East (2009-2012). Available from: http://maps.nrcgit.ru/geoterm/ (last accessed 11.06.2019).

Gan W., Zhang P., Shen Z.-K., Niu Z., Wang M., Wan Y., Zhou D., Cheng J., 2007. Present-Day Crustal Motion within the Tibetan Plateau Inferred from GPS Measurements. Journal of Geophysical Research 112 (B8), B08416. https://doi. org/10.1029/2005JB004120.

Gatinsky Yu.G., 1986. Lateral Structural-Stratigraphic Analysis. Nedra, Moscow, 195 p. (in Russian) [Гатинский Ю.Г. Латеральный структурно-формационный анализ. М.: Недра, 1986. 195 с.].

Gatinsky Y.G., Prokhorova T.V., 2014. Superficial and Deep Structure of Central Asia as Example of Continental Lithosphere Heterogeneity. Universal Journal of Geoscience 2 (2), 43-52.

Gatinsky Y.G., Prokhorova T.V., 2015. Seismic Active Zones in South Siberia, Russian Far East, and Adjacent Countries. Russian Journal of Earth Sciences 15 (3), ES3003. http:// dx.doi.org/10.2205/2015ES000554.

Gatinsky Y.G., Prokhorova T.V., Rundquist D.V., 2017a. Geodynamics and Seismicity of the Eastern Part of Central Asia. Doklady Earth Sciences 472 (1), 119-122. https:// doi.org/10.1134/S1028334X17010226.

Gatinsky Y.G., Prokhorova T.V., Rundquist D.V., 2017b. Zones of the Origin of Seismic Centers in the Pamir - Tien Shan Sector of High Asia. Doklady Earth Sciences 475 (2), 887890. https: //doi.org/10.1134/S1028334X17080049.

Gatinsky Y.G., Prokhorova T.V., Rundquist D.V., 2018. The $102-103^{\circ} \mathrm{E}$ Geodivider in the Modern Lithosphere Structure of Central Asia. Geodynamics \& Tectonophysic. 9 (3), 9891006. https://doi.org/10.5800/GT-2018-9-3-0380.

Gatinsky Y.G., Prokhorova T.V., Rundquist D.V., Vladova G.L., 2009. Zones of Catastrophic Earthquakes of Central Asia: Geodynamics and Seismic Energy. Russian Journal of
Earth Sciences 11 (1), ES1001. https://doi.org/10.2205/ 2009ES000326.

Gatinsky Yu.G., Rundquist D.V., 2004. Geodynamics of Eurasia: Plates Tectonics and Blocks Tectonics. Geotectonics 38 (1), 1-16 [Гатинский Ю.Г., Рундквист Д.В. Геодинамика Евразии: тектоника плит и тектоника блоков // Геотектоника. 2004. Т. 38. № 1. C. 3-20].

Gatinsky Y.G., Rundquist D.V., Cherkasov S.V., 2005. Geodivider of $102-103^{\circ}$ in East Asia: Geological and Metallogenic Signs. In: Tectonics of Earth Crust and Mantle. Tectonic Regularities of Minerals Placing. Proceedings of the 28th Tectonic Conference. GEOS, Moscow, p. 127-130 (in Russian) [Гатинский Ю.Г., Рундквист Д.В., Черкасов С.В. Геораздел $102-103^{\circ}$ на востоке Азии: геологические и металлогенические признаки // Тектоника земной коры и мантии. Тектонические закономерности размещения полезных ископаемых: Материалы 28-го Тектонического совещания. М.: ГЕОС, 2005. С. 127-130].

Gatinsky Yu.G., Rundquist D.V., Vladova G.L., Prokhorova T.V., 2008. Geodynamics of the Sichuan Earthquake Region in May 12, 2008. Doklady Earth Sciences. 423 (2), 15071509. https://doi.org/10.1134/S1028334X08090419.

Gatinsky Y.G., Rundquist D.V., Vladova G.L., Prokhorova T.V., 2011. Up-To-Date Geodynamics and Seismicity of Central Asia. International Journal of Geosciences 2 (1), 1-12. https://doi.org/10.4236/ijg.2011.21001.

Gatinsky Y.G., Vladova G.L., 2008. Subduction zones of SE Asia: Main Types, Seismicity and Mineralization. In: Proceedings of the Vag International Symposium (November 7-9, 2008, Hanoi, Vietnam). Special Issue of Journal of Geology: International Year of Planet Earth, p. 9-16. Available from: http://idm.gov.vn/nguon_luc/Xuat_ban/2008/b3132/b9.htm.

Grachev A.F., Kalashnikov I.V., Magnitsky I.V., 1993. Modern and Recent Geodynamics and Seismicity of China. Physics of the Earth (10), p. 3-13 (in Russian) [Грачев А.Ф., Калашникова И.В., Магницкий И.В., 1993. Современная и новейшая геодинамика и сейсмичность Китая // Физика Земли. № 10. C. 3-13].

Heidbach O., Rajabi M., Reiter K., Ziegler M., WSM Team, 2016. World Stress Map Database Release 2016. GFZ Data Services. https://doi.org/10.5880/WSM.2016.001.

Hu J., Yang H., Xu X., Wen L., Li G., 2012. Lithospheric Structure and Crust - Mantle Decoupling in the Southeast Edge of the Tibetan Plateau. Gondwana Research 22 (3-4), 1060-1067. https://doi.org/10.1016/j.gr.2012.01.003.

Huang J., Zhao D., 2009. Seismic Imaging of the Crust and Upper Mantle under Beijing and Surrounding Regions. Physics of the Earth and Planetary Interiors 173 (3-4), 330348. https://doi.org/10.1016/j.pepi.2009.01.015.

Kanamori H., Anderson D.L., 1975. Theoretical Basis of Some Empirical Relations in Seismology. Bulletin of the Seismological Society of America 65 (5), 1073-1095.

Komarov Yu.V., Belichenko V.G., Misharina L.A., Petrov P.A., 1978. The Verkhoyansk-Burmese Junction Zone of the Central and East Asian Structures (VEBIRS Zone). In: VEBIRS Trans-Continental Zone. ESB of the USSR Acad. Science, Irkutsk, p. 5-24 (in Russian) [Комаров Ю.В., Беличенко В.Г., 
Мишарина Л.А., Петров П.А. Верхояно-Бирманская зона сочленения Центрально- и Восточноазиатских структур (Зона ВЕБИРС) // Трансазиатская континентальная зона ВЕБИРС (оперативная информация). Иркутск: ВСФ СО АН СССР, 1978. С. 5-24].

Korhonen J.V., Fairhead J.D., Hamoudi M., Hemant K., Lesur V., Mandea M., Maus S., Purucker M., Ravat D., Sazonova T., Thébault E., 2007. Magnetic Anomaly Map of the World. Map Published by Commission for Geological Map of the World, Supported by Unesco, 1st Edition, GTK, Helsinki. Available from: http://projects.gtk.fi/WDMAM/project/perugia/.

Kozhevnikov V.M., Yanovskaya T.B., 2005. S-Waves Velocities Distribution in the Asian Continent Lithosphere after Data on Superficial Reley Waves. In: K.G. Levi, S.I. Sherman (Eds), Central Asia Geodynamics Actual Problems. SB RAS Publishing House, Novosibirsk, p. 46-64 (in Russian] [Koжевников В.М., Яновская Т.Б. Распределение скоростей $\mathrm{S}$-волн в литосфере Азиатского континента по данным поверхностных волн Релея // Актуальные проблемы геодинамики Центральной Азии / Ред. К.Г. Леви, С.И. Шерман. Новосибирск: Изд-во СО РАН, 2005. С. 46-64].

Kuchai O.A., Kozina M.E., 2010. Regional Features of Seismotectonic Deformations in East Asia Based on Earthquake Focal Mechanisms and Their Use for Geodynamic Zoning. Russian Geology and Geophysics 56 (10), 1467-1475. https:// doi.org/10.1016/j.rgg.2015.09.011.

Legendre C.P., Zhao L., Chen Q.-F., 2015. Upper-Mantle Shear-Wave Structure under East and Southeast Asia from Automated Multimode Inversion of Waveforms. Geophysical Journal International 203 (1), 707-719. https://doi. org/10.1093/gji/ggv322.

Li S., Unsworth M.J., Booker J.R., Wei W., Tan H., Jones A.G., 2003. Partial Melt or Aqueous Fluid in the Mid-Crust of Southern Tibet? Constraints from INDEPTH magnetotelluric data. Geophysical Journal International 153 (2), 289-304. https://doi.org/10.1046/j.1365-246X.2003.01850.x.

Li J., Wang X., Niu F., 2011. Seismic Anisotropy and Implication for Mantle Deformation beneath the NE Margin of the Tibet Plateau and Ordos Plateau. Physics of the Earth and Planetary Interiors 189 (3-4), 157-170. https://doi. org/10.1016/j.pepi.2011.08.009.

Liu-Zeng J., Zhang Z., Wen L., Tapponnier P., Sun J., Xing X., Hu G., Q.Xu, Zeng L., Ding L., Ji C., Hudnut K.W., Van der Woerd J., 2009. Co-Seismic Ruptures of the 12 May 2008, Ms 8.0 Wenchuan Earthquake, Sichuan: East-West Crustal Shortening on Oblique, Parallel Thrusts along the Eastern Edge of Tibet. Earth and Planetary Science Letters 286 (3-4), 355-370. https://doi.org/10.1016/j.epsl.2009.07.017.

Lysak S.V., 2009. Thermal History, Geodynamics, and Current Thermal Activity of Lithosphere in China. Russian Geology and Geophysics 50 (9), 815-825. https://doi.org/ 10.1016/j.rgg.2009.08.007.

Miroshnichenko A.I., San'kov V.A., Parfeevets A.V., Lukhnev A.V., 2007. State of Stress and Strain of the Earth Crust of the Basins of North Mongolia from the Model Results. In: Proceedings of the Conference Commemorating the 50th Anniversary of the 1957 Gobi-Altay Earthquake (25 July 8 August, 2007, Ulaanbaatar, Mongolia) Extended Abstract
Volume. Center of Astronomy and Geophysics Mongolian Academy of Sciences, Ulaanbaatar, p. 138-143.

Molnar P., Tapponier P., 1975. Cenozoic Tectonics of Asia: Effects of a Continental Collision. Science 189 (4201), 419426. https://doi.org/10.1126/science.189.4201.419.

Parfeevets A.V., San'kov V.A., 2018. Geodynamics Conditions of Cenozoic Activization in Tectonic Structures of Southeast Mongolia. Geodynamics \& Tectonophysic 9 (3), 855888. https://doi.org/10.5800/GT-2018-9-3-0374.

Rundquist D.V., Gatinsky Yu.G., Cherkasov S.V., 2004. The Natural Trans-Eurasian Divider: Structural and Metallogenic Evidence. In: Abstracts Volume of the 32nd International Geological Congress, Part 2. Florence, Italy, p. 620.

San'kov V.A., Parfeevets A.V., Lukhnev A.V., Miroshnichenko A.I., Ashurkov S.V., 2011. Late Cenozoic Geodynamics and Mechanical Coupling of Crustal and Upper Mantle Deformations in the Mongolia-Siberia Mobile Region. Geotectonics 45 (5), 378-393. https://doi.org/10.1134/S001685 2111050049.

San'kov V.A., Lukhnev A.V., Miroshnichenko A.I., Dobrynina A.A., Ashurkov S.V., Byzov L.M., Dembelov M.G., Calais E., Déverchère J., 2014. Contemporary Horizontal Movements and Seismicity of the South Baikal Basin (Baikal Rift System). Izvestiya, Physics of the Solid Earth 50 (6), 785-794. https://doi.org/10.1134/S106935131406007X.

San'kov V.A., Parfeevets A.V., Miroshnichenko A.I., San'kov A.V., Bayasgalan A., Battogtokh D., 2015. Active Faults Paragenesis and the State of Crustal Stresses in the Late Cenozoic in Central Mongolia. Geodynamics \& Tectonophysics 6 (4), 491-518 (in Russian) [Саньков B.А., Парфеевец А.В., Мирошниченко А.И., Саньков А.В., Баясгалан А., Баттогтох Д. Парагенез активных разломов и позднекайнозойское напряженное состояние земной коры центральной части Монголии // Геодинамика и тектонофизика. 2015. Т. 6. № 4. С. 491-518]. https://doi.org/10. 5800/GT-2015-6-4-0191.

Seminskii K.Zh., 2008. Hierarchy in the Zone-Block Lithospheric Structure of Central and Eastern Asia. Russian Geology and Geophysics 49 (10), 771-779. https: //doi.org/ 10.1016/j.rgg.2007.11.017.

Shen Z.K., Lü J., Wang M., Bürgmann R., 2005. Contemporary Crustal Deformation around the Southeast Borderland of the Tibetan Plateau. Journal of Geophysical Research: Solid Earth 110 (B11), B11409. https://doi.org/10.1029/ 2004JB003421.

Sherman S.I., 2012. Destruction of the lithosphere: FaultBlock Divisibility and Its Tectonophysical Regularities. Geodynamics \& Tectonophysics 3 (4), 315-344 (in Russian) [Шерман С.И. Деструкция литосферы: разломно-блоковая делимость и ее тектонофизические закономерности // Геодинамика и тектонофизика. 2012. Т. 3. № 4. C. 315-344]. https://doi.org/10.5800/GT-2012-3-4-0077.

Sherman S.I., 2015. Localization of Recent Strong Earthquakes in Central Asia: A Rare Combination of Geodynamic and Trigger Factors. In: V.V. Adushkin, G.G. Kocharian (Eds), Trigger effects in geosystems. GEOS, Moscow, p. 138-149 (in Russian) [Шерман С.И. Локализация современных сильных землетрясений в Центральной Азии: редкое 
сочетание геодинамических и триггерных факторов // Триггерные эффекты в геосистемах / Ред. В.В. Адушкин, Г.Г. Кочарян. М.: ГЕОС, 2015. С. 138-149].

Sherman S.I., 2016. Tectonophysical Signs of the Formation of Strong Earthquake Foci in Seismic Zones of Central Asia. Geodynamics \& Tectonophysics 7 (4), 495-512 (in Russian) [Шерман С.И. Тектонофизические признаки формирования очагов сильных землетрясений в сейсмических зонах Центральной Азии // Геодинамика и тектонофизика. 2016. Т. 7. № 4. С. 495-512]. https://doi.org/ 10.5800/GT-2016-7-4-0219.

Sherman S.I., Ma Jin, Gorbunova E.A., 2015. Recent Strong Earthquakes in Central Asia: Regular Tectonophysical Features of Locations in the Structure and Geodynamics of the Lithosphere. Part 1. Main Geodynamic Factors Predetermining Locations of Strong Earthquakes in the Structure of the Lithosphere in Central Asia. Geodynamics \& Tectonophysics 6 (4), 409-436. https://doi.org/10.5800/GT-2015-6-4-0188.

Sherman S.I., Zlogodukhova O.G., 2011. Seismic Belts and Zones of the Earth: Formalization of Notions, Positions in the Lithosphere and Structural Control. Geodynamics \& Tectonophysics 2 (1), 1-34 (in Russian) [Шерман С.И., Злогодухова О.Г., 2011. Сейсмические пояса и зоны Земли: формализация понятий, положение в литосфере и структурный контроль // Геодинамика и тектонофизика. Т. 2. № 1. C. 1-34]. https://doi.org/10.5800/GT-2011-2-1-0031.

Solon K.D., Jones A.G., Nelson K.D., Unsworth M.J., Kidd W.F., Wei W., Tan H., Jin S., Deng M., Booker J. R., Li S., Bedrosianet P., 2005. Structure of the Crust in the Vicinity of the BanggongNujiang Suture in Central Tibet from Indepth Magnetotelluric Data. Journal of Geophysical Research: Solid Earth 110 (B10), B10102. https://doi.org/10.1029/2003JB002405.

Tan W., Shen Z., 2008. Heat Flow Distribution in Chinese Continent and Its Adjacent Areas. Progress in Natural Science
18 (7), 843-849. http://dx.doi.org/10.1016/j.pnsc.2008. 01.018.

Tectonic Map of China and Adjacent Regions, 1999. Compiled by the Tectonic Division of the Institute of Geology, Chinese Academy of Geological Sciences. Chief compiler Ren Jishun. 1st ed. Geological Publishing House, Beijing.

The Global Heat Flow Database, 2011. International Heat Flow Commission. University of North Dakota. Available from: http://www.heatflow.und.edu.

Trifonov V.G., Soboleva O.V., Trifonov R.V., Vostrikov G.A., 2002. Recent Geodynamics of the Alpine-Himalayan Collision Belt. GEOS, Moscow, 225 p. (in Russian) [Трифонов В.Г., Соболева О.В., Трифонов Р.В., Востриков Г.А. Современная геодинамика Альпийско-Гималайского коллизионного пояса. М.: ГЕОС, 2002. 225 с.].

Wang Ch.-Yo., Yang W.-C., Wu J.-P., Ding Z.-F., 2015. Study on the Lithospheric Structure and Earthquakes in NorthSouth Tectonic Belt. Chinese Journal of Geophysics - Chinese Edition 58 (11), 3867-3901.

Wang X.-S., Lü J., Xie Z.-J., Long F., Zhao X.-Y., Zheng Y., 2015. Focal Mechanisms and Tectonic Stress Field in the North-South Seismic Belt of China. Chinese Journal of Geophysics - Chinese Edition 58 (11), 4149-4162.

Xu X., Deng Q., 1996. Nonlinear Characteristics of Paleoseismicity in China. Journal of Geophysical Research: Solid Earth 101 (B3), 6209-6231. https://doi.org/10.1029/95J B01238.

Yuan X., Egorov A.S., GEMOC, 2000. A Short Introduction to Global Geoscience Transect 21: Arctic Ocean - Eurasia Pacific Ocean. Science Press, $32 \mathrm{p}$.

Zonenshain L.P., Savostin L.A., 1981. Geodynamics of the Baikal Rift Zone and Plate Tectonics of Asia. Tectonophysics 76 (1-2), 1-45. https://doi.org/10.1016/0040-19 51(81)90251-1.

\section{YURY G. GATINSKY}

Doctor of Geology and Mineralogy

Institute of Earthquake Prediction Theory and

Mathematical Geophysics of RAS

84/32 Profsoyuznaya St, Moscow 117997, Russia

e-mail: gatinsky@gmail.com

ORCID: 0000-0001-7225-7073

\section{TATIANA V. PROKHOROVA}

Research Scientist

Institute of Earthquake Prediction Theory and Mathematical Geophysics of RAS

84/32 Profsoyuznaya St, Moscow 117997, Russia

e-mail: tatprokh@mitp.ru

ORCID: 0000-0002-8829-2081

\section{ЮРИЙ ГЕОРГИЕВИЧ ГАТИНСКИЙ}

докт. геол.-мин. наук

Институт теории прогноза землетрясений и математической геофизики РАН

117997, Москва, ул. Профсоюзная 84/32, Россия 


\section{DMITRY V. RUNDQUIST}

Doctor of Geology and Mineralogy

V.I. Vernadsky State Geological Museum of RAS

11-11 Mokhovaya St, Moscow 125009, Russia

e-mail:dvr@sgm.ru

ORCID: 0000-0001-8428-5936
ДМИТРИЙ ВАСИЛЬЕВИЧ РУНДКВИСТ

докт. геол.-мин. наук

Государственный геологический музей

им. В.И. Вернадского РАН

125009, Москва, ул. Моховая 11, стр. 11, Россия 